

\title{
Yuk Ming Dennis Lo
}

\author{
Germano de Sousa ${ }^{1}$
}

A propósito do artigo sobre a trissomia 21, incluído neste número da Gazeta Médica, justo é lembrar o Dr. Dennis Lo, o médico (por Oxford), investigador e professor de Patologia Química da Universidade Chinesa da sua terra natal Hong Kong, que transformou a prática da obstetrícia enquanto pai dos testes pré-natais não invasivos (non-invasive prenatal testing - NIPT).

Tendo em 1997 descoberto a presença de DNA fetal no sangue materno, ${ }^{1}$ a sua investigação sobre o tema levou-o a desenvolver metodologias fiáveis de separação entre o DNA fetal e maternal circulantes bem como o diagnóstico pré-natal das aneuploidias cromossómicas do feto (trissomias 21, 13 e 18), ${ }^{2}$ com 100\% de sensibilidade e $98 \%$ de especificidade. ${ }^{3}$

Em 2010, com a sua equipa faz a primeira e completa sequenciação do genoma fetal a partir do DNA isolado no sangue materno, ferramenta que pode permitir detectar a existência neste de mutações de novo e facilitar o estudo de alterações epigenómicas. ${ }^{4}$

Em 1917 a equipe de Dennis Lo, utilizando uma tecnologia da área da transcriptómica identificou e esclareceu a dinâmica celular da placenta normal e a disfunção placentária da pré-eclâmpsia. Demonstrou também que as alterações placentárias podem ser identificadas no DNA materno circulante no plasma. ${ }^{4}$

O Dr. Lo é também um pioneiro no desenvolvimento e aplicação em oncologia da tecnologia conhecida por "biópsia líquida". Assim em 2013 defendeu e comprovou o conceito de que as alterações encontradas no DNA das células cancerosas podem ser detectadas no DNA livre circulante e libertado por essas células tumorais. ${ }^{5}$

Como é sabido a identificação, por técnicas de biologia molecular (polimerase chain reaction real time, polimerase chain reaction digital, next generation sequencing, etc.), das alterações encontradas no DNA do genoma das várias neoplasias (mutações, fusões de genes, etc.) era e é feita, mais tipicamente, em tecido tumoral obtido através de biópsias tissulares cruentas. No seguimento dos trabalhos de Dennis Lo, outros investigadores aperfeiçoaram a "biópsia líquida", tecnologia incruenta que, não apenas completou como se tornou numa alternativa à biópsia tissular e uma ferramenta com um impacto cada vez mais significativo no screening, diagnóstico, ajuda à decisão terapêutica, progressão e desfecho da doença oncológica.

Actualmente a "biópsia líquida" permite isolar, a partir de uma simples colheita de 10 a 20 mL de sangue periférico, o DNA livre, oriundo de qualquer neoplasia existente no organismo ou de eventuais metástases que se possam desenvolver, mesmo após ser removido cirurgicamente o tumor primário, designadamente aquelas cuja localização se desconhece ou com um acesso que as torna impossíveis de biopsar, e de seguida submeter esse DNA às técnicas de biologia molecular já referidas. Claro que a questão que imediatamente se coloca é a da representatividade deste DNA tumoral relativamente ao tumor primário e metástases. Entre os muitos estudos de validação que demonstram a concordância 
entre estes, ressalta pela escala, o estudo apresentado na reunião anual de 2016 da American Society of Clinical Oncology que reporta uma avaliação genómica de 15000 doentes com cancros avançados. Neste estudo a concordância entre a caracterização genómica do DNA circulante com a do tumor primário, sequenciado a partir de tecido biopsado foi de $87 \%$, chegando aos $98 \%$ quando a colheita de sangue e do tecido foi feita com menos de seis meses de intervalo, sugerindo que a menor concordância reflectia apenas evolução do tumor. ${ }^{6}$

Como vimos o Dr. Lo e os NIPT estiveram na origem das biópsias líquidas. Por isso mesmo e por ironia o seu NIPT foi vítima do DNA circulante dos tumores maternos sendo esta uma das causas, das raríssimas causas, geradoras de falsos positivos do NIPT. Em 2013 Osborne et al descreveram o caso de uma grávida cujo NIPT realizado em duas amostras de sangue diferentes era sugestivo de aneuploidia 13 e 18. Não só o cariotipo era inteiramente normal como a criança também o era. Na continuidade e após uma fractura espontânea do púbis percebeu-se que havia um tumor metastizado e que as células do tumor primitivo apresentavam aneuploidias 13 e 18, o que significou que ao isolar-se o DNA do feto se isolou simultaneamente o DNA do tumor não se descortinando nenhuma alteração ao método que pudesse evitar esse percalço.

Depois destes alguns casos têm sido referidos na literatura. Na longa experiência que sobre estes testes temos no nosso laboratório nada de semelhante encontrámos. Apenas as gravidezes gemelares podem dificultar a especificidade do teste.

Termino como comecei, louvando o patologista químico Dr. Dennis Lo pela importância que teve e terá nestas áreas da medicina laboratorial desejando-Ihe uma longa vida para continuar a surpreender-nos com a sua investigação e descobertas.

CONFLITOS DE INTERESSE: Os autores declaram não possuir conflitos de interesse.

SUPORTE FINANCEIRO: O presente trabalho não foi suportado por nenhum subsidio o bolsa ou bolsa.

PROVENIÊNCIA E REVISÃO POR PARES: Comissionado; não teve revisão externa por pares.

CONFLICTS OF INTEREST: The authors have no conflicts of interest to declare.

FINANCIAL SUPPORT: This work has not received any contribution grant or scholarship.

PROVENANCE AND PEER REVIEW: Commissioned; not externally peer reviewed.

\section{REFERÊNCIAS}

1. Lo YM, Corbetta N, Chamberlain PF, Rai V, Sargent IL, Redman CW, et al. Presence of fetal DNA in maternal plasma and serum. Lancet. 1997; 350:485-7

2. Chiu RW, Chan KC, Gao Y, Lau VY, Zheng W, Leung TY, et al. Noninvasive prenatal diagnosis of fetal chromosomal aneuploidy by massively parallel genomic sequencing of DNA in maternal plasma. Proc Natl Acad Sci U S A. 2008;105:20458-63.

3. Chiu RW, Akolekar R, Zheng YW, Leung TY, Sun H, Chan KC, et al. Non-invasive prenatal assessment of trisomy 21 by multiplexed maternal plasma DNA sequencing: large scale validity study. BMJ. 2011; 342:c7401. doi: 10.1136/bmj.c7401.

4. Lo YM, Chan KC, Sun H, Chen EZ, Jiang P, Lun FM, et al. Maternal plasma DNA sequencing reveals the genome-wide genetic and mutational profile of the fetus. Sci TransI Med. 2010; 2:61ra91. doi: 10.1126/scitransImed.3001720.

5. Chan KC, Jiang P, Chan CW, Sun K, Wong J, Hui EP,et al. Noninvasive detection of cancer-associated genome-wide hypomethylation and copy number aberrations by plasma DNA bisulfite sequencing.Proc Natl Acad Sci U S A. 2013; 110:18761-8. doi: 10.1073/ pnas.1313995110.

6. Zill OA, Mortimer S, Banks KC, Nagy RJ, Chudova D, Jackson C, et al. Somatic genomic landscape of over 15,000 patients with advanced-stage cancer from clinical next-generation sequencing analysis of circulating tumor DNA.J Clin Oncol.2016;34 (Suppl.LBA):11501.

7. Osborne CM, Hardisty F, Devers P, Kaiser-Rogers K, Hayden MA, Goodnight W, et al. Discordant noninvasive prenatal testing results in a patient subsequently diagnosed with metastatic disease. Prenatal Diagn. 2013: 33:609-11. doi: 10.1002/pd.4100. 